\title{
Study on Development of Learning Media
}

\author{
Muhammad Ediyani $^{1}$, Ulfi Hayati ${ }^{1}$, Salwa $^{1}$, Samsul $^{2}$, Nursiah ${ }^{1}$ M. Bahriza Fauzi ${ }^{1}$ \\ ${ }^{1}$ Sekolah Tinggi Ilmu Tarbiyah (STIT) Syamsuddhuha, Indonesia \\ ${ }^{2}$ Teacher \\ Ediyani03@gmail.com
}

\begin{abstract}
The development of science and technology is increasingly encouraging renewal efforts in the use of technological outcomes in the teaching and learning process. The teachers are required to be able to use the tools that can be provided by the school, and it is also possible that the tools are in accordance with the development and demands of the times. The teachers can at least use inexpensive and unpretentious tools but is a necessity in the effort to achieve the expected learning goals. The development of instructional media is a plan to develop existing media or intermediary tools in order to improve the quality of information delivery in the teaching-learning process. Development activities learning media in broad outline must go through three major steps namely planning, production and penialian activities.
\end{abstract}

Keywords

development; learning Media

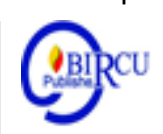

\section{Introduction}

Learning media is one of the elements that plays an important role in the learning process. Learning media are learning resources that can help teachers enrich students' insights. Various forms and types of learning media used by teachers will be a source of knowledge for students.

The use of learning media in the teaching-learning process can arouse new desires and interests for students. The use of learning media at the learning orientation stage will greatly assist the effectiveness of the learning process and the delivery of messages and lesson content.

With the increasingly widespread progress in the field of communication and technology, as well as the discovery of the dynamics of the teaching-learning process, the implementation of teaching-learning activities increasingly demands to be developed for a wide variety of learning media.

Therefore, the authors in this paper want to explain about the development of learning media as a contribution to developing science in the hope that readers are able to understand and know about the development of learning media.

\section{Review of Literature}

\section{Learning Media Development}

According to the Indonesian Dictionary, development is a process / way, the act of developing. In term of development, it shows that an activity produces a new tool or method, during which the activity will continue to be evaluated and improved to improve quality. So that development can be defined as a plan to develop something that already exists in order to improve the quality of more advanced. 
The development of technology, communication and information, especially the internet has become a demand for teachers in Indonesia to be able to use it as a source of positive learning media in supporting teaching and learning processes (Prasasti, 2019).

While the word media comes from Latin medius, which means literal, means middle, intermediary, or introduction. In Arabic, the media is an intermediary (سنائنلَو) or an introduction to the message from the sender to the recipient of the message. Gerlach and Ely said that the media are human, material, or events that establish conditions that make students able to obtain knowledge, skills, or attitudes. More specifically, the notion of media in the teaching and learning process tends to be interpreted as graphic, photo, or electronic tools for capturing, processing, and rearranging visual or verbal information.

Dewi (2019) states that Media is a facilities that should be utilized maximally due to develop the student's motivation in learning. Learning tools basicallydefined as all tools that have a function to help the teacher to deliver learning material to the students in order to achieve the learning goal.

The Association for Education Cummunications and Technology (AECT) defines media as all forms used to distribute information. So that the media can be defined as an intermediary tool used in the framework of communication and interaction between educators and students in the learning process.

According to the opinion of the authors of media development is a plan to develop media or intermediary tools that already exist in order to improve the quality of information delivery in the teaching-learning process.

Before developing the learning media, several criteria must be considered in selecting learning media so that the teaching-learning process runs smoothly and in accordance with the objectives set. Some criteria in choosing the following learning media:

1. In accordance with the objectives to be achieved. The media are chosen based on instructional goals that have been set both in terms of cognitive, affective, and psychomotor.

2. The media must be appropriate to support the content of lessons that are facts, concepts, principles or generalization.

3. The media must be practical, flexible and enduring. If there is no time, funds or other resources available to produce, it does not need to be forced. Media that is expensive and takes a long time is not a guarantee as the best media. So the teacher can choose the available media, easily obtained and easily made by the teacher. The selected media should be used wherever and whenever with existing equipment in the surrounding environment, and is easy to carry and move anywhere.

4. The media must be able to be used by teachers well and skillfully. Whatever the medium, the teacher must be able to use it in the learning process. Computers, transparency projectors (OHP), slide projectors, and films, and other sophisticated equipment will not mean anything if the teacher has not been able to use them in teaching and learning in class.

5. Technical quality. Visual development of both images and photography must meet certain technical requirements. For example the visuals on the slides must be clear and the information or messages that are highlighted and want to be conveyed should not be disturbed by other elements in the form of background.

6. The media used must be in accordance with the level of thinking of students.

7. The media used must be able to support and help students' understanding of the lesson so that the learning process can run smoothly and in accordance with the learning objectives to be achieved. 


\section{Discussion}

\subsection{Steps in Developing the Learning Media}

Learning media is a tool used in the teaching-learning process that can arouse interests and desires, student motivation, and can even bring psychological influences on students. Therefore, the development of learning media is very important to shape the effectiveness of the learning process and delivery of messages and content, so that learning objectives can be achieved optimally. Learning media development activities in general must go through three major steps, namely planning, production and assestment activities.

\section{a. Planning the Learning Media}

When educators want to develop learning media the first step taken is to make careful preparation and planning. In order to design or develop a media program, educators need to pay attention and consider the following steps:

\section{Analyze the Student Needs and Characteristics}

The need for teaching and learning is the gap between what students have and what is expected. For example if we expect students to speak Arabic properly and correctly, while they are only able to recite hijaiyah letters, then it is necessary to do exercises to memorize vocabulary and practice it.

After we analyze the needs of students, then we also need to analyze the characteristics of students, both regarding the ability of knowledge or skills that students have had before. The way to find out is by knowing it with others. This step can be simplified by identifying topics of teaching material that are considered difficult and therefore require media assistance. In this step, at the same time the realm of learning objectives can be determined, including which sensory stimuli are needed (audio, visual, motion or still).

With these needs so that it becomes the basis for developing learning media, because with the encouragement of these needs the media can function properly. And the media used by students, must be relevant to the abilities of students.

\section{Formulate the Learning Objectives}

To be able to formulate learning goals properly, there are several provisions that must be kept in mind, namely: learning objectives must be student-oriented; meaning that the goal really must state the existence of student behavior that can be done or obtained after the learning process is done.

A learning goal should have four main elements that we can acronym in ABCD (Audience, Behavior, Condition, and Degree). Explanation of each component is as follows:

a. Audience is to mention the target / learner who is the target of learning

b. Behavior is stating the specific behavior that is expected or can be done after learning takes place.

c. Condition is to mention the conditions under which or where the target can demonstrate his abilities or skills.

d. Degree is to mention the level of success that is expected to be achieved by students.

Example of Learning Objectives:

After attending the Arabic Learning Media course, STIT Syamsuddhuh students can develop Arabic Learning Media properly and correctly.

Audience $\quad=$ STIT student Syamsuddhuha

Behavior $=$ Developing Arabic Language Learning Media

Condition $=$ after taking the Arabic Learning Media course

Degree $\quad=$ Well and truly 


\section{Development of Learning Materials}

Learning material is knowledge, skills, and attitudes that must be mastered by students in order to meet the specified competency standards. In developing the material, the actions taken next analyze the objectives that have been determined into well-organized sub-skills and sub-skills, so that detailed teaching materials are obtained that can support these objectives. The list of abilities is the teaching material presented to students. In this way a complete teaching material can be obtained and can achieve the stated goals.

After the list of subjects of learning materials can be arranged well, then organize the sequence of presentation, namely from simple things to complicated things, from concrete things to abstract things, from the specific to general matters.

There are several types of learning material that can be classified as follows:

a. Facts are all things that are tangible reality and truth.

b. Concepts are all things in the form of new notions that can arise as a result of thought.

c. The principle is in the form of the main things, principal, and has the most important position.

d. Procedures are systematic or sequential steps in working on an activity and chronology of a system.

e. Attitudes or values are the result of learning aspects of attitude, for example the value of honesty, compassion, help, enthusiasm, and interest in learning and working.

Determination of learning material can take the following steps:

a. Identification of competency standards and basic competencies

Before determining the learning material, it is first necessary to identify aspects of the integrity of competencies that students must learn or master. These aspects need to be determined, because each standard of competence and basic competencies that must be mastered by students includes cognitive, psychomotor or affective domains.

b. Identification of the types of learning material

Identification is carried out related to the suitability of learning material with the level of activity / learning domain. Learning materials need to be properly identified so that the achievement of their competencies can be measured. In addition, by identifying the types of material to be learned, the teacher gets accuracy in the learning method. Because, each type of learning material requires a different strategy, method, media and evaluation system.

\section{Development of Measuring Tools for Success}

Measuring success tools should be developed first before writing the program script. This measuring device must be developed in accordance with the objectives to be achieved and from the learning materials presented. The form of measuring devices can be biased with tests, observations, assignments or behavior checklists. In writing scientific papers, technicallythe language needs to be considered when writing direct or indirect quotations, writing reference lists, writing words, writing abbreviations, writing punctuation marks, using sentences, especially reasoning sentences. Reasonable reasoning is sentences whose contents are acceptable by common sense (Sitepu, 2019).

The instrument will be used by media developers, when conducting trials of media programs that they develop. For example the test gauge, then students will be asked to work on these materites. Then see how it works. Does the student show a good mastery of the material from the effects of the media used or from the material learned through media presentations? If not, where are the disadvantages? Thus, students are asked for responses about the media, both in terms of attractiveness and effectiveness of the presentation.

As one example of measuring the success of the media developed by teachers is as follows: 


\begin{tabular}{|c|l|l|}
\hline Formulation of Purpose & Material Formulation & Measuring Instruments (Tests) \\
\hline $\begin{array}{l}\text { Students can mention the } \\
\text { types of sentences in Arabic }\end{array}$ & $\begin{array}{l}\text { Types of sentences in } \\
\text { Arabic }\end{array}$ & $\begin{array}{l}\text { Mention Types of sentences in } \\
\text { Arabic! }\end{array}$ \\
\hline
\end{tabular}

From the example above, it is clear that the preparation of measuring instruments for success must be based on the formulation of objectives and learning material that will be taught through these learning media.

\section{Media Script Writing}

Media script is a form of presentation of learning material through design media which is a translation of the subject matter that has been arranged properly as described above. So that the learning of the length can be conveyed through the media, the article is called a slump in the writing or picture that we call the media program. The purpose of the media program script is to guide us in producing media. So that the text becomes our claimant in taking pictures and recording sound, because this script contains a sequence of images and graphics that need to be taken by the camera or sounds and sounds that must be recorded. In technical writing, the script is carried out through stages. The stages in making or writing a script are originated from the existence of ideas and ideas that are tailored to the learning objectives. Then collecting data and information, writing synopsis and treatment, writing the script, reviewing the script or revising the script, until the script is ready for production.

\section{b. Learning Media Production}

Previously it has been discussed that the writing of manuscripts serves as a guide in production. This production activity has three groups of personnel involved, namely the director or production leader, work relatives, and performers. The three groups of personnel have different duties and responsibilities but all of them aim at one goal which is to produce media programs that have good technical quality.

Production programs have different levels of complexity between media. For example in the production of audio media can be done by a director with the help of two technicians and several players. Whereas in the production of audio-visual media, the number of work relatives needed is greater, which consists of working relatives to record audio, cameramen, lighting, makeup, setting regulators, equipment interpreters and note-takers, because of the complexity of the work, the director needs assisted by the assistant director.

\section{c. Learning Media Evaluation}

Evaluation of learning media is an action process or activity carried out with a view to determining the value of all media or tools used in teaching and learning activities. This assessment is intended to find out the media made can achieve the goals set. When evaluating the learning media, the main question that often arises is what must be evaluated, this means that each evaluator looks back at the functions and principles of media use.

In evaluating the learning media, psychological aspects need to be considered. Because this psychological aspect makes people have different learning styles. According to Michael Gardner there are three learning styles that humans have: visual learning styles (learning by seeing), audiotorial learning styles (learning by listening) and kinesthetic learning styles (learning by moving, working and touching). The test or trial can be done either through individuals or through small groups or also through field tests, namely in the actual learning process by using media that is developed. While revision is an activity to improve the things that are deemed necessary to get improvements on the results of the test.

The evaluation objectives in the development of learning media include:

1. Determine the effectiveness of the learning media used. 
2. Determine the improvement or improvement of learning media.

3. Establish the cost-effective media used, seen from student learning outcomes.

4. Select the appropriate learning media to be used in the learning process in the classroom.

5. Determine the accuracy of the content of the lessons presented with the media.

6. Assess the teacher's ability to use learning media.

7. Knowing that the learning media really contribute to the results of learning as expected.

8. Knowing students' attitudes towards learning media.

If related to the evaluation objectives as stated, then there are various types of evaluation of the learning media. Based on the process, this media evaluation consists of formative evaluation and summative evaluation. Formative evaluation is a process that is intended to collect data about the effectiveness and efficiency of learning materials (in this case the medium) to achieve the stated goals. The data is intended to improve and perfect the media concerned to be more effective and efficient. In its final form, after the media is corrected and refined, data will be collected to determine whether the media is suitable for use in certain situations or the media is truly effective as reported. This type of evaluation is then called summative evaluation. There are three stages in evaluating or assessing a learning medium including:

\section{One by One Evaluation}

At this stage a designer chooses several students (no more than three) who can represent the target population of the media created. Serve these media to them individually. If the media is designed for independent learning, let students learn it, while the developer observes it. The two students who have been chosen should be one person from the target population who are capable who more person than average are generally slightly below average and one. In other words, in determining this group the variation in academic ability of the target population is considered.

\section{Small Group Evaluation}

At this stage the media needs to be tested on 10-12 students who can represent the target population. The number 10 is the minimum amount, because if it is less than that amount the data obtained is less able to describe the target population. Conversely, if more than 12, data or information exceeds what is needed, the result is less useful to be analyzed in small groups. Students selected in this activity should reflect the characteristics of the population. Try the sample consisting of students who are less intelligent, moderate, and smart, male and female, various ages and backgrounds.

\section{Field Evaluation}

Field evaluation is the final stage of formative evaluation that needs to be done. The field evaluation was attempted as closely as possible to the actual situation. After going through the two stages of evaluation above, surely the media made are nearing perfection. But with that matter still has to be proven. Through this field evaluation, the ability of the media that we make is tested. In conducting field evaluations, a designer selects about 30 students while paying attention to various characteristics such as intelligence, social class, background, gender, age, learning progress, and so on according to the characteristics of the target.

If all these steps have been taken and are considered to be no longer need to be revised, then the next step is the media is ready to be produced. However, it can happen after production. It turns out that after it has been distributed or presented there are some deficiencies in the material aspects or the quality of the media presentation (picture or sound), in such cases it can also be improved (revised) for aspects that are considered lacking. This is done to get perfection from the media created, so that its users will easily receive messages conveyed through these media. 


\section{Conclusion}

The development of learning media is a plan to develop existing media or intermediary tools in order to improve the quality of information delivery in the teaching-learning process. Learning media development activities in general must go through three major steps, namely planning, production and penialian activities. In the production of learning media development there are several principles that must be considered, namely:

1. Analyze the students' needs and characteristics.

2. Formulate the learning objectives.

3. Development of learning materials.

4. Formulation of a measure of success.

5. Writing the script.

If all of these steps have been taken, then the next step is that the media is ready to be produced. However, it can happen after production. It turns out that after it has been distributed or presented there are some deficiencies in the material aspects or the quality of the media presentation (picture or sound), in such cases it can also be improved (revised) for aspects that are considered lacking. This is done to get perfection from the media created, so that its users will easily receive messages conveyed through these media.

\section{References}

Akabar, Sa'dun Instrumen Perangkat Pembelajaran, Bandung: Remaja Rosdakarya, 2013.

Anitah, Sri, Media Pembelajaran, Surakarta: LPP UNS dan UNS Press, 2009.

Arsyad, Azhar, Media Pembelajaran, Jakarta: Rajawali Pers, 2006.

Asnawir dan Bsyiruddin Usman. Media Pembelajaran. Jakarta: Ciputat Press, 2002.

Depdiknas, Panduan Pengembangan Indikator, Jakarta: Dirjen Manajemen Dikdasmen, 2008

Dewi, N.R., et al. (2019). Moodle Cloudas the Developing Listening E-Learning Media in

SMP Negeri 7 Medan. Britain International of Linguistics, Arts and Education (BIoLAE) Journal, 272-277.

Kustandi, Cecep dan Bambang Sutjipto, Media Pembelajaran: Manual dan Digital, Bogor: Ghalia Indonesia, 2011.

Prasasti, T.I., et al. (2019). The Effectiveness of Learning Media Folklore Text of North Sumatera Based on Blended Learning by $10^{\text {th }}$ Grade Students of Vocational High School Harapan Mekar-1 Medan. 480-490

Sadiman, Arief S. et al, Media Pendidikan: Pengertian, Pengembangan, dan Pemanfaatannya, Jakarta: Raja Grafindo Persada, 1996.

Sitepu, T. (2019). Cooperative Model in Language Reasoning: Indonesian Language Teaching Materials in Teacher Training and Education Faculty of Muhammadiyah Sumatera Utara University. Britain International of Linguistics, Arts and Education (BIoLAE) Journal, 51-59.

Sukiman, Pengembangan Media pembelajaran, Yogyakarta: Pustaka Insan Madani, 2012.

Sutopo, Hendayat dan Westy Soemanto, Pembinaan dan Pengembangan Kurikulum Sebagai Substansi Problem Administrasi Pendidikan, Jakarta: Bumi Aksara, 1993.

Tim Penyusun Kamus Pusat Bahasa, Kamus Besar Bahasa Indonesia, Jakarta: Balai Pustaka, 2007. 